\title{
Micromorphology of Cave Sediments in the Humid Tropics: Niah Cave, Sarawak
}

\author{
(Q) (Q) (0) \\ MARK STEPHENS, JAMES ROSE, DAVID GILBERTSON, \\ AND MATTHEW G. CANTI
}

INVESTIGATIONS OF THE MICROMORPHOLOGICAL PROPERTIES of archaeologically important cave deposits are rare in the humid tropics. Only five published accounts have been located by the authors (see below). This paper uses the explanatory power of micromorphology to interpret the palaeoenvironmental history of the sediments preserved in the West Mouth of the Great Cave of Niah. Attention is given to the deposits exposed in new or cleaned exposures in the deep section known as Hell Trench excavated by Tom and Barbara Harrisson in the 1950s and 1960s, and by Zuraina Majid in the 1970s, and reinvestigated by the Niah Cave Project in recent years (Barker et al. 2000, 2001, 2002; Fig. 1; see also this volume: Barker, Figs. 3 and 4; Gilbertson et al., Figs. 1 and 2). The Hell Trench yielded the oldest modern human remains from Southeast Asia, the so-called Deep Skull dated to about 45,000-43,000 B.P. (Barker et al. 2001, 2002; Harrisson 1970; Zuraina 1982; this volume: Gilbertson et al.), the bestknown find of the vast collection of human, vertebrate, and invertebrate remains recovered from the site preserved in the Niah Cave Archive in the Sarawak Museum, Kuching.

The geological, topographic, and environmental situations of this cave have been summarized in a number of publications (Banda and Heward 2000; Barker et al. 2000, 2001; Hazebroek and Morshidi 2001; Hutchinson 1989; Wilford 1964; see also this volume: Gilbertson et al.). In brief, the Great Cave of Niah is a vast $(\mathrm{ca} .900 \times 600 \mathrm{~m})$ multichambered and multientranced cave developed within the Subis Limestone Member (Miocene) of the hill massif known as the Gunong Subis. The cave mouth of the west entrance is ca. $150 \mathrm{~m}$ wide and ca. $60 \mathrm{~m}$ high. A rampart is developed at the cave mouth, rising some $3-4 \mathrm{~m}$ above the adjacent interior cave surface. The rampart is derived from the collapse of a

Mark Stephens and James Rose, Department of Geography, Royal Holloway, University of London; David Gilbertson, School of Conservation Sciences, Bournemouth University, and School of Geography, University of Plymouth; Matthew G. Canti, Ancient Monuments Laboratory, English Heritage, Fort Cumberland. 
curtainlike set of massive stalactite columns, only one of which remains in situ. Outside the cave mouth, there is a gorge several hundred meters wide, eroded into the Subis Limestone. The gorge and surrounding lowland support dense tropical rainforest growing in a hot and humid monsoonal environment.

The superficial deposits exposed by previous excavations formed a cave floor that sloped downward from the cave interior toward the cave mouth at $2-8^{\circ}$ (Wilford 1964: Plates LVI and LVII). Wilford (1964) described the importance in the cave of airfall guano from the many bat and bird inhabitants. Following this line of reasoning, Harrisson $(1958,1970)$ also interpreted the sediments that he excavated as primarily formed by vertical accretion of (pink) airfall guano with the addition of (white) debris from the (mainly) limestone bedrock. Additionally, he recognized the presence of material from the activities of animals and people. The reinvestigations by the Niah Cave Project agree with the importance of airfall guano for understanding part of the geomorphic sequence exposed in the excavations, but many other aspects of the earlier interpretations have been challenged (this volume: Gilbertson et al.).

In the following text the first reference to technical micromorphological terms is highlighted with an asterisk and explained in a glossary at the end of the paper.

\section{THE FIELD EVIDENCE}

The architecture of the archaeologically important sediments exposed in the cave entrance is shown in Figure 1. These are primarily fine-grained, varying from slightly clayey sands to silty clays. Four major sedimentary units or lithofacies* have been recognized in this area, and three of these are considered in this study (Barker et al. 2001, 2002; this volume: Gilbertson et al.). The Deep Skull was found within sediments defined as Unit 2: beds of red-brown silty clays, silts, and sands. These beds display sedimentary structures that indicate complex origins: there are fluvial and pond lithofacies with evidence of episodic desiccation, interbedded palaeosols, and colluvial* layers from the cave rampart. Unit 2 also displays deformation structures that demonstrate the lateral impact on it of the mass movement deposit (Unit 3) that once flowed toward the cave mouth from the higher interior of the cave. Unit 3 is a pink silt with diagenetic* growths of white gypsum. This is clearly the sterile "pink and white" deposit noted by Harrisson (1958) and Zuraina (1982). The last major lithofacies considered here is Unit 2C, a yellowish clayey silt on the cave mouth side of the Hell Trench containing lithics, ash, and charcoal. It is poorly sorted, but shows weak downslope bedding, and contains palaeosols. It is above and partly interbedded with the fluvial/pond deposits of Unit 2.

While it is possible to detect these deposits in the many publications of Harrisson (Barker et al. 2002; this volume: Gilbertson et al.), their stratigraphic significance was not identified in the earlier excavations, in part probably because of the poor illumination of the exposures in the Hell Trench, but also because of the very difficult working conditions that led to its naming by the Harrisson team. Micromorphological studies are therefore especially useful in these circumstances for studying the sedimentary properties under optimal working conditions and for identifying critical environmental proxies that are not visible in the field. 


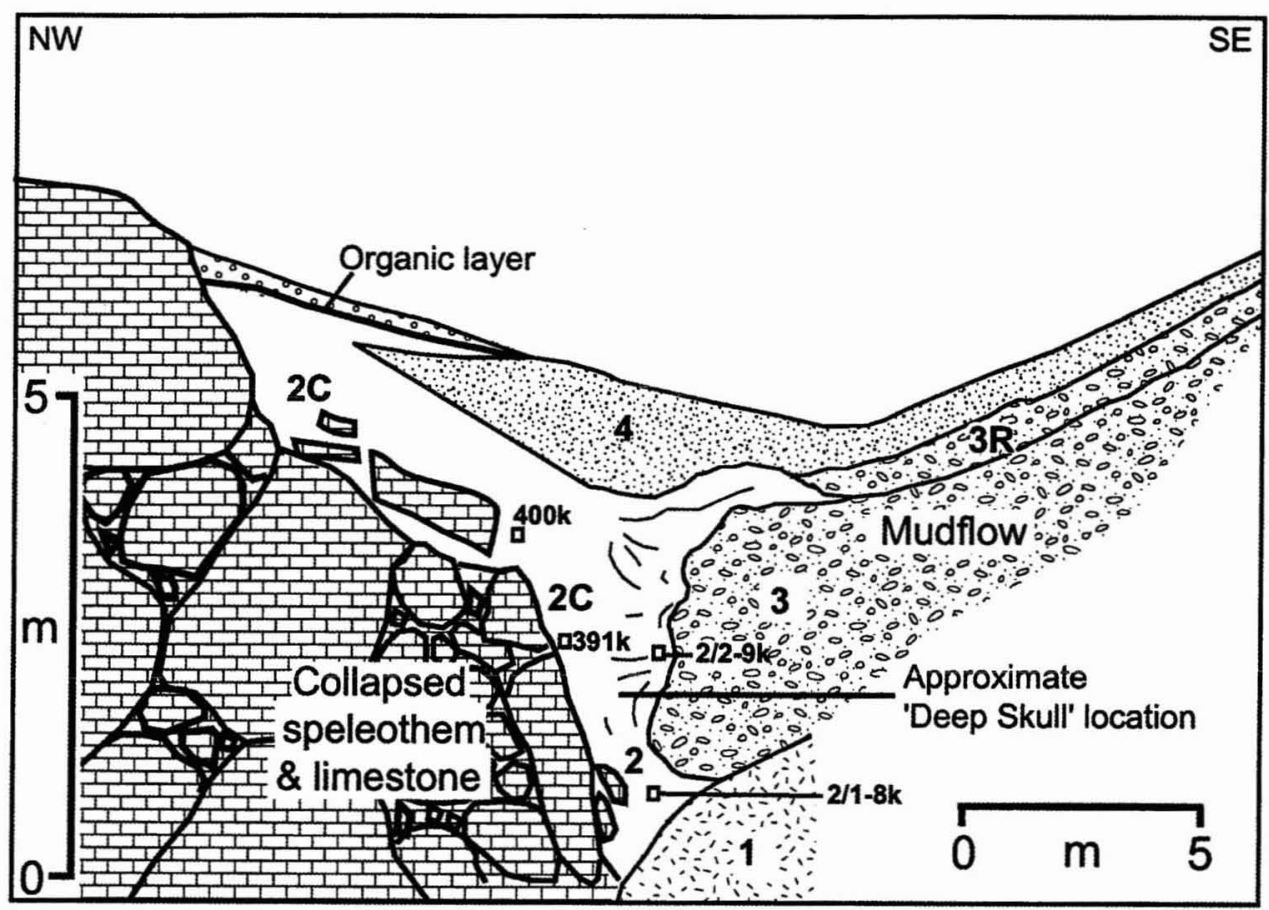

Fig. 1. The West Mouth of Niah Great Cave: schematic representation of sedimentary Units or Lithofacies 1-4 showing the locations of the Deep Skull and the Kubiena tin (k) sampling points for micromorphology. (Adapted from Barker et al. 2001)

\section{PREVIOUS WORK ON THE MICROMORPHOLOGY OF HUMID TROPICAL CAVE SEDIMENTS}

Frank (1981) used micromorphology to study the sediments in the limestone Leang Burung 2 cave, Indonesia. He analyzed cemented deposits and noted clay, quartz silt, and fragments of micropeds, ${ }^{*}$ gastropod shell, bone, and a variety of rock lithologies. He also found invertebrate burrow molds and claimed that the preservation of these was aided by post-depositional calcium carbonate precipitation.

Magee and Hughes (1982) analyzed the Colless Creek (Queensland, northern Australia) dolomite cave sediments along with modern soils. They found soil aggregates* with silt-size quartz inclusions that showed greater rounding in the cave sediments than in the surface soil, thought to be due to transport from above. A basal unit is described without such soil aggregates and attributed to compaction as a result of wetting-and-drying cycles and carbonate solution. Manganese nodules, voids, and grain coatings* are also present in the deposits, indicating the movement of water through the profiles.

Gillieson and Mountain (1983), working in the Nombe limestone rock shelter, Papua New Guinea, reported clay aggregates with an isotropic* matrix* (Bullock et al. 1985), pisoliths, ${ }^{*}$ tephra, ${ }^{*}$ clay clumps containing bone and previously burnt soil, calcium carbonate void linings and infillings, burnt bone and soil peds, ${ }^{*}$ charcoal, and limestone fragments. 
Magee (1988) made micromorphological analyses of sediments from the Hagop Bilo limestone rock shelter in Madai Baturong, Sabah, to assist both stratigraphic correlation and environmental interpretation. Basal "pre-occupation sediments" containing fine grain laminations and graded bedding are interpreted as alluvial floodplain deposits. The "human-occupation sediments" displayed an open, disturbed fabric with sediment aggregates including charcoal, bone, and shell fragments. Magee (1988) notes the presence of such aggregates in other cave sites associated with human occupation, and suggests that their genesis could be influenced by anthropogenic activity since they incorporate archaeological material. Post-depositional alteration was also noted, with the formation of manganese nodules.

McConnell and Magee (1993) presented a review of previously published (including Magee 1988; Magee and Hughes 1982) and new micromorphological results from several sites in Australasia and Southeast Asia, which were prompted by questions concerning sedimentology, provenance, and reworking. The main occupation deposits in limestone rock shelters at Balof 2 (New Ireland, Papua New Guinea) were found to be homogeneous and considered to be the result of reworking by wasps, other soil microfauna (producing extremely fine granular excrement), and possibly people. Bioturbation* was less important at the rear of the shelter. Calcite-poor red and yellow clays were interpreted as soil material from outside the cave.

Although of interest and value as pioneering works, these papers provide limited detail. Often, there are no descriptions of features to aid identification. For example, Gillieson and Mountain (1983) make references to a "burnt ped" but do not describe how identification was made. There is also a lack of visual aids such as photomicrographs. Here, we attempt to build on these pioneering studies. The micromorphology is placed in the context of site geomorphology (Fig. 1), and supported by a semi-quantitative microfeature frequency chart (Table 1), and photomicrographs (Fig. 2).

\section{SAMPLE PREPARATION, ANALYSIS, AND PROVENANCE}

Kubiena tins* were used to sample the soft, clayey Niah Cave sediments. This texture contrasts with the typically clastic* cave sediments of more temperate regions (e.g., Farrand 1975; Goldberg 1979; Kiernan 1983), and greatly aids sampling for micromorphology. Thin-section sample preparation followed routine procedures described in Lee and Kemp (1994). Micromorphological terminology is derived mostly from Brewer (1976) and Bullock et al. (1985), with additions from van der Meer (1993). Selection of sample points for micromorphology (Fig. 1) was determined by questions identified in the field, and the full context of all these sample points is made clear in Barker et al. $(2000,2001,2002)$ and Gilbertson et al. (this volume).

The samples discussed here derive from materials that were deposited shortly before and after ca. 38,000 B.P., when this part of the West Mouth was struck by the mass movement deposit (Unit 3) that moved toward the cave mouth from its source in a large guano mound several hundred meters farther into the cave. The samples from Unit 2C (\#400k and \#391k) are close to the cave mouth and part of a sedimentary unit that slopes from the cave rampart down to the channel fill. 
Table i. Microfeatures Observed in the Thin Section Samples from the West Mouth of the Great Cave of Niah. Both Frequency Scales from Bullock et al.

(I985) are Used. Four Dots Represent Features that can be Very Dominant (>70\%), Three Dots Represent those Features that Can be Very Abundant (>20\%)

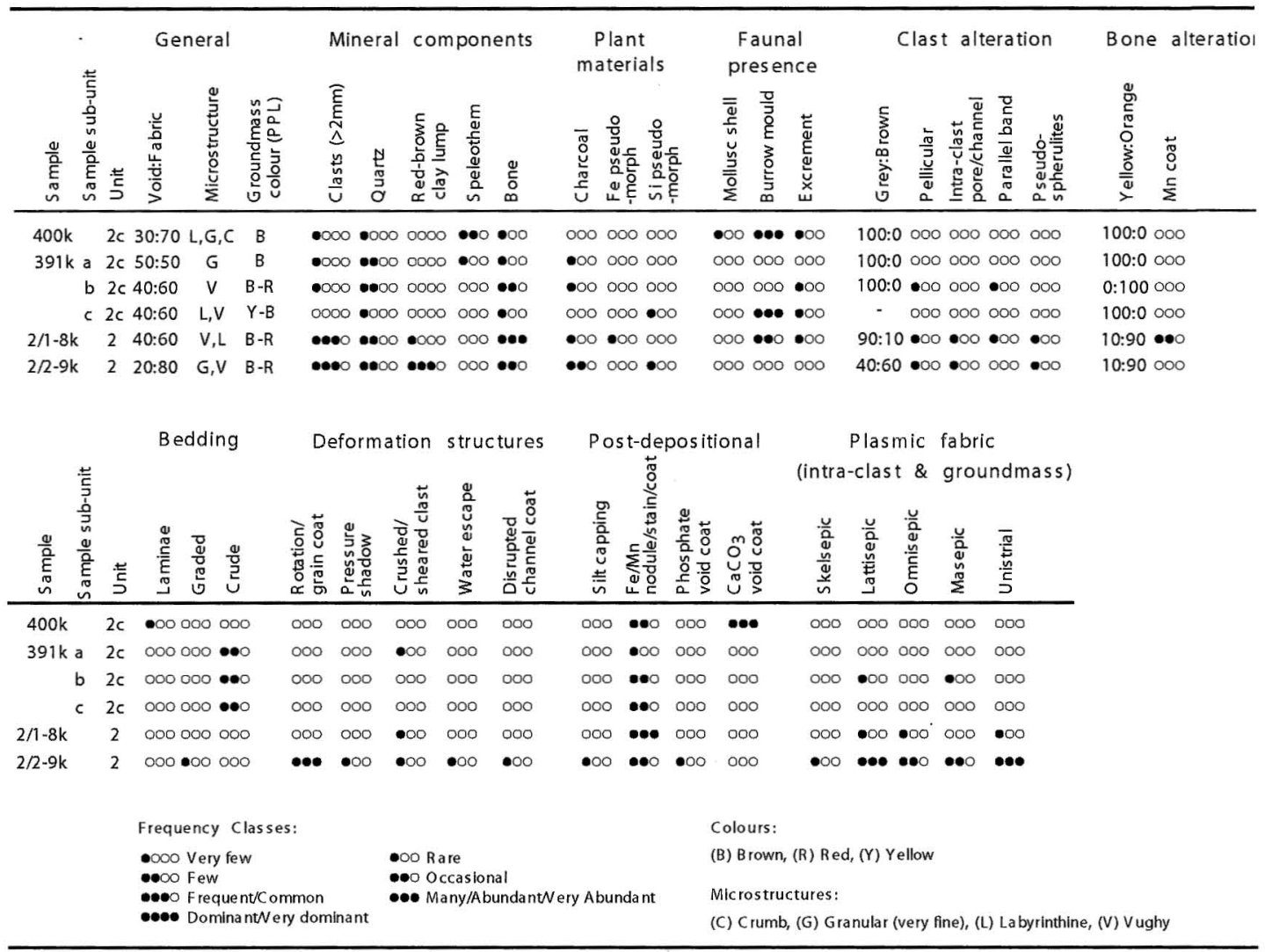

Samples \#2/2-9k and \#2/1-8k are taken from the stream and pond sediments of Unit 2, which, in its upper part, is interbedded with the colluvium of Unit 2C. The waterlain deposits of Unit 2 are deformed by the mass movement deposit (Unit 3). Sample \#391k (subunit b) is also taken from Unit 2C in order to examine palaeosurface materials containing archaeological remains and sample \#2/2-9k is taken to include material deposited close to the contact with Unit 3. The palaeosurface in sample \#391k(b) appears in the field to be at or close to the stratigraphic position of the Deep Skull (Fig. 1).

\section{RESULTS AND INTERPRETATION}

Table 1 presents a summary of the micromorphological features present, together with a semi-quantitative indication of frequency. To avoid repetition, the following diagnostic criteria are used for interpretation of the following features:

- Clasts* have grey/brown fabrics and abundant silt-size quartz.

- Bone has a ropy texture in crossed polarized light* (XPL) (Courty et al. 1989). 


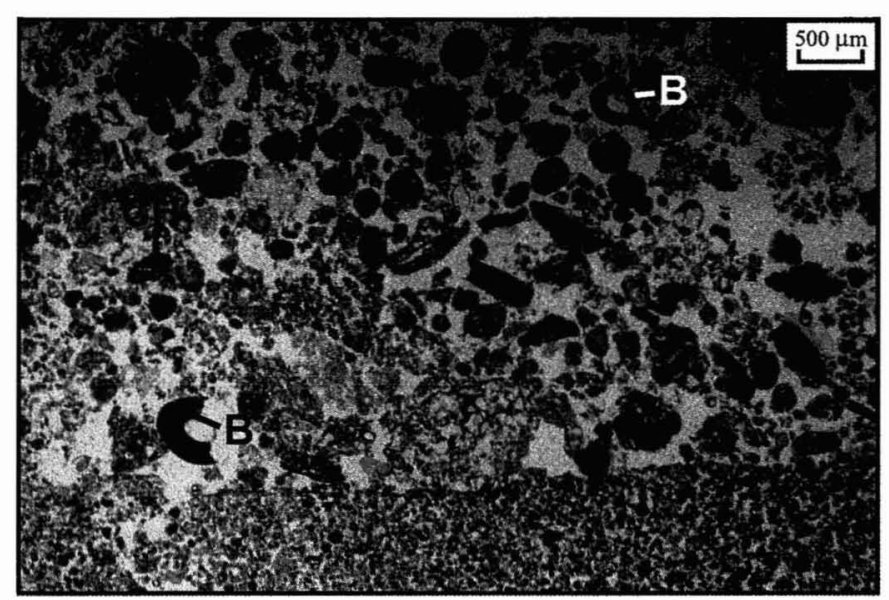

(a)

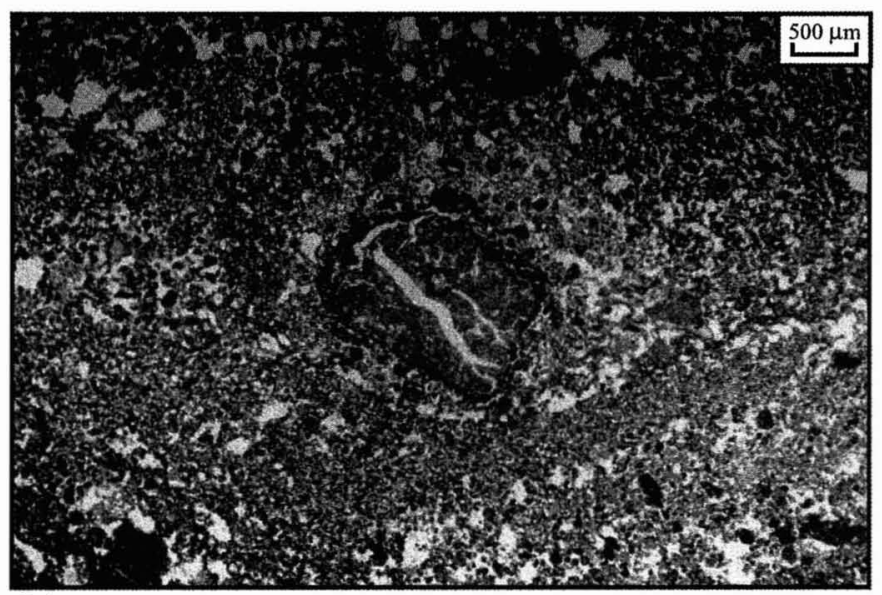

(b)

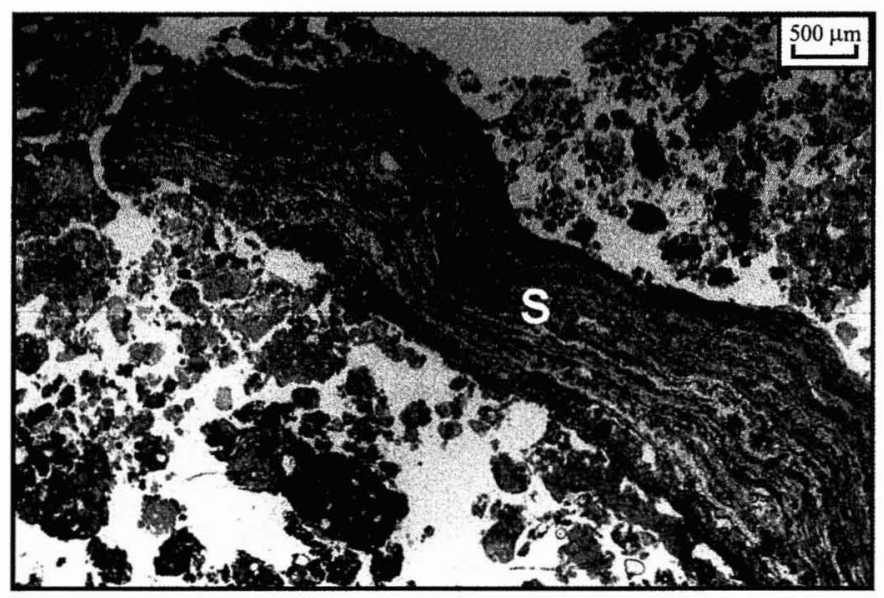

(c)
Fig. 2. Photomicrographs of sediments from Niah Cave West Mouth (plane polarized light): a: sample \#2/2-9k: well-sorted overlain by moderately sorted stream sediments with an erosive, sharp, contact, and localized transport and deposition of bone (B) and charcoal $(\mathrm{CH})$; b: sample \#2/2-9k: fractured clast (C) with a pressure shadow of finer sediment around; the clast is also part of a rotational structure and acts as the corestone; c: sample \#391k: porous speleothem fragment (S) with internal undulate lamination. 
- Phosphates are pale yellow or orange in color in plane polarized light* (PPL) and isotropic in XPL (Courty et al. 1989).

- Charcoal is black and shows the original cellular plant structure (Courty et al. 1989).

- Iron and/or manganese is typically a black or brown-red stain, nodule, or void coat (Courty et al. 1989).

- Calcium carbonate has high-order interference colors* (Bullock et al. $1985: 66)$ in XPL.

- Plasmic fabric* is highly birefringent* when viewed in XPL. These interference colors are caused by the reorientation of clay particles by physical stress by deformation (van der Meer 1993) or shrink/swell processes (Lafeber 1964).

- Red-brown clay lumps are rounded to subangular, and typically contain silt and some sand-size quartz inclusions. They also have a noticeable plasmic fabric.

\section{PALAEOSURFACE LITHOFACIES ASSOCIATED WITH THE DEEP SKULL}

Table 1 shows that sample \#391k(b), associated with the palaeosurface in Unit 2C, exhibits similar features to samples \#2/1-8k and \#2/2-9k of Unit 2, suggesting a close relationship. These similarities include vughy* microstructure; brown-red groundmass; black, aggregated iron/manganese nodules and stains; a few quartz grains; occasional, predominantly orange-colored, small bone fragments; and charcoal and clast alteration. Samples \#2/1-8k and \#2/2-9k are, however, richer in clasts and red-brown clay lumps, possibly reflecting deposition of larger particles in the main stream channel.

The red-brown clay lumps typically have silt-size quartz inclusions. This may be due to quartz being rolled along a sticky clay surface (sample \#2/2-9k has abundant coated quartz grains, Table 1) or the transport to the site of red soil aggregates (Alberts et al. 1980) from land surfaces above the cave. This latter process has been described in modern analogue studies (Brinkmann and Reeder 1995; Frank 1968; McConnell and Magee 1993). In addition to the above processes it should also be noted that reddening of sediments can occur as the result of burning (Isaac 1982), and the presence of charcoal suggests that this may be a factor contributing to the micromorphology of material in Unit 2.

Further evidence that Unit 2 is waterlain is the presence of well-sorted sand, sharply overlain by moderately sorted sand and silt containing charcoal and small bone fragments (Fig. 2a). This suggests accumulation in a small stream or pool with ephemeral influxes of material. The presence of charcoal may be interpreted in several ways: (1) it might indicate the direct presence of human occupation contemporary with the deposition of the sands; (2) it might indicate reworking of material associated with a previous occupation; or (3) it might indicate charcoal blown into the cave from fires elsewhere. It is not yet possible to determine which. Also observable in sample \#2/2-9k are two successive phases of graded crusts which are typical of wetting-and-drying cycles, reflecting the development of a shallow pond.

The clast alteration present in samples \#2/2-9k, \#2/1-8k, and \#391k(b) includes pore development and pellicular* and parallel banding (Bullock et al. 1985). Due to this form of alteration gray clasts become red-brown in color in PPL and brown-red in XPL, suggesting oxidation of iron minerals or burning. 
Pseudospherulites are also present within clasts. These features are circular in shape, 50-100 $\mu \mathrm{m}$ diameter, brown in PPL, brown-orange in XPL, and orange in oblique incident light (OIL) (Courty et al. 1989:48). An extinction cross* (Bullock et al. 1985:52) is present in XPL. These spherulites* are not yet fully understood, but since they are typically concentrated in the periphery of clasts they may be the result of clast weathering. The bone present also indicates weathering (Table 1) as it is orange-colored rather than the creamy yellow color typical of fresh bone (Stiner et al. 1995).

Sample \#2/2-9k shows a fragmented, vertical, dark orange (PPL), isotropic (XPL), phosphatic clay channel coating (length $=4.5 \mathrm{~mm}$, width $=500 \mu \mathrm{m}$ ). This is explained by the vertical translocation of phosphate material, formed by the alteration of guano or bone. This feature could indicate a period of soil formation with translocation* through an upper horizon, or a surface water flow resulting in the deposition of fine clays down desiccation cracks. The latter explanation is supported by the wetting-and-drying crustal features of sample \#2/2-9k, and wetting-and-drying cycles could also explain the fragmentation of the channel coat. Overall, these features suggest numerous episodes of wetting and drying, owing perhaps to a more seasonal climate, as postulated by Gilbertson et al. (this volume) from field observation of polygonal mud rip-up clasts in Unit 2.

Other sedimentary features noticeable from sample \#2/2-9k include a semicruciform channel feature with sorted materials. This is interpreted as a waterescape structure (van der Meer 1993), and indicates instability caused by rapid sedimentation or a shock. Additionally, the presence of a fractured grain with a pressure shadow of finer silt-sized material in the center of this structure shows that there has been rotational movement during the water escape (Fig. 2b). Sample \#2/2-9k also exhibits strong plasmic fabrics and clasts/quartz grains with abundant fine coats that are most likely the result of simple shear or rotation. All of these features are typical of deformed sediment (van der Meer 1993), and probably reflect either very rapid sedimentation or, more likely, the shock caused by the impact of the Unit 3 mass failure on Unit 2 and the lower part of Unit 2C.

In general, samples \#2/2-9k and \#2/1-8k from Unit 2 display a diamictic* structure. This could be due to (1) poor sorting during deposition, (2) mixing caused by the impact of the Unit 3 mudflow, or (3) mixing and the inclusion of coarser material by bioturbation (McConnell and Magee 1993). Bioturbation burrow molds are indeed present in sample \#2/1-8k. They are typically $\sim 4 \mathrm{~mm}$ diameter, smoothly curved voids with densely packed walls. The voids commonly have a partial infill of very fine $(<100 \mu \mathrm{m})$ granular material (termed labyrinthine microstructure* [Fitzpatrick 1984]). It is evident that fauna $<4 \mathrm{~mm}$ in diameter are creating burrows and producing a very fine granular material in the process (sample \#2/2-9k also has such a granular microstructure; Table 1).

A few void walls of sample \#2/1-8k are, however, concave inward and interpreted as having collapsed, possibly the result of human trampling. Features indicating the former presence of plant materials are also present: faintly cellular, gray (PPL), isotropic (XPL) phytoliths* (sample \#2/2-9k); cellular, orange (PPL), isotropic (XPL), red-brown (OIL) Fe plant pseudomorphs* indicating trapped iron consequent upon plant decomposition (\#2/1-8k; Table 1) (Courty et al. 1989: 180). Plant materials in the cave could be associated with human activity. 
Sample \#391k (Unit 2C) shows three subunits (a, b, and c) in thin section distinguished mainly by groundmass color (PPL). Micromorphological analysis of the lower brown part (a) of sample \#391k shows crude bedding, diamictic structure, subrounding to angular clasts, and a sheared clast, features that are considered in the context of the site location to be produced by slope processes. A gray-brown (PPL) clast with internally contorted laminae is also visible in this subunit of the thin section, and is interpreted as a fragment of speleothem derived from the nearby growths at the cave mouth (Fig. 2c). This clast is, however, isotropic (XPL), suggesting the presence of diagenetically produced phosphate minerals from contact with phosphate-rich guano (Karkanas et al. 2000). Further chemical analysis will be needed to test this interpretation. There is no other evidence of clast alteration in sample \#391k(a) (Table 1), suggesting less weathering than in Unit 2. In addition, bone fragments in the lower and upper parts of sample \#391k are a pale yellow-white color, indicating better preservation than elsewhere. The presence of charcoal in sample \#391k(a) suggests human activity. The upper subunit (c) of sample \#391k shows an absence of clasts, rare amounts of fine silt-size quartz, abundant burrow molds, and rare cellular (ca. $250 \times 500$ $\mu \mathrm{m}$ diameter) isotropic phytoliths. (These phytoliths are abundant in palynology preparations: Chris Hunt pers. comm.) The phosphatic (groundmass isotropic in XPL), clay-rich upper part of sample \#391k extends several meters laterally in the field and is likely to be the product of guano deposition, with little input from other sources.

Sample \#400k was collected from homogeneous yellow sticky clay in Unit 2C, located ca. $10 \mathrm{~m}$ northward from sample \#391k. Micromorphology reveals a highly calcareous groundmass with speleothem fragments (internal laminae, grey [PPL], high order interference colors [XPL]). Both of these properties are likely due to the proximity of the calcareous dripline and speleothem at the cave entrance. These properties further highlight the wide range of facies present in the cave entrance (Frank 1968; Schmid 1963). Bioturbation burrow molds are also common in this sample. They appear as oval voids with compressed walls and contain loose continuous mamillate* excrement. Identical bioturbation burrow features are observed in the phosphatic material in the upper part of sample \#391k (Table 1), reflecting either the preference of the fauna for particular substrates or the preservation potential of the material (Frank 1981). The latter explanation is preferred, as burrowing bees are currently active in all deposits. A zone of fine silt and clay laminae is preserved in sample \#400k and gives an evidence of the predisturbance deposit formed by the precipitation of calcium carbonate from highly alkaline water. Rounded clasts are also present in sample \#400k, again indicating deposition by moving water.

The identification in sample \#400k of fragments $(<100 \mu \mathrm{m}$ length) of bivalve mollusks that do not inhabit the cave suggests human input. Reprecipitation of calcium carbonate as void coats and infillings and iron and manganese as dark brown and red mottling of groundmass and hypocoatings* could indicate soil formation despite the evidence for soil formation at the macroscale.

Quartz grains are present in small numbers in all the deposits studied. They are 
typically silt-size and randomly dispersed throughout the matrix-dominated deposits. The quartz is subrounded to angular, suggesting an aeolian derivation.

\section{CONCLUSIONS}

This is one of the first detailed accounts of the micromorphology of archaeologically important tropical cave sediments. Micromorphology has identified important archaeological materials such as bone fragments, shell, and charcoal. Qualitative descriptions and semi-quantitative summaries of these materials and microfeatures provide a basis for a detailed palaeoenvironmental interpretation of the deposits associated with the Deep Skull at the West Mouth of Niah Great Cave, and of the post-depositional alteration that has occurred at the site.

A wide variety of sediment types is present, including the red, iron-rich Unit 2 sediments and the calcium carbonate- and phosphate-rich Unit $2 \mathrm{C}$ deposits. These lithofacies reflect different sources of material that can be influenced by a variety of factors, including wet/dry conditions in the external environment, the cave topography, the proximity to the cave entrance dripline, and guano production.

Micromorphology of the sediments that yielded the Deep Skull (Unit 2) indicates deposition in water alternating with periods of desiccation. This wetting and drying may be due to a more seasonal climate, as also postulated from the macroscale field evidence (this volume: Gilbertson et al.). Micromorphology also confirms the importance of slope (colluvial) processes from the cave mouth rampart (in the form of structures and materials) and the impact within Unit 2 of the catastrophic mudflow event Unit 3 (in the form of microscale deformation structures).

Micromorphology provides abundant evidence for post-depositional alteration in the form of color changes, chemical alteration of material structure and faunal bioturbation structures, and general disturbance of the original sedimentary structures and fabric. In particular, micromorphology highlights the importance of very transient soil formation producing limited sediment alteration that is not visible in the field.

Overall, the micromorphology appears to corroborate field interpretations of the depositional environments, as well as provide important new information regarding the provenance of materials and processes in operation. The study demonstrates that micromorphological research can significantly enhance understanding of archaeologically important cave sediments in the humid tropics through the detailed reconstruction of palaeoenvironments, as well as detecting some of the consequences of past human activity.

\section{ACKNOWLEDGMENTS}

This research has been funded primarily by the Arts and Humanities Research Board (UK), through its support for the Niah Cave Project coordinated by Professor Graeme Barker. The laboratory work has also been supported by financial contributions from the School of Conservation Sciences at Bournemouth University and Royal Holloway, University of London. The authors thank Adrian Palmer for help with preparation of the thin sections in the laboratories of the Department of Geography, Royal Holloway. 


\section{GLOSSARY}

For convenience, these definitions are tuned to the content of this paper.

aggregates: discrete clusters of particles

bioturbation: the activity of organisms disturbing sediment

birefringent: having light splitting into two beams of unequal velocities, producing strong colors

clastic: consisting of rock fragments

clasts: rock fragments

coating: a layer of material (usually clay or calcium carbonate) around a grain or a void

colluvial: formed by slope processes

crossed polarized light (XPL): light, viewed through a polarizing microscope, that has transmission planes at right angles

diagenetic: alterated after deposition by processes within the material (sediment)

diamictic: nonsorted sediment with a wide range of particle sizes

extinction cross: a black cross caused by complete darkness obtained in a birefringent material during the rotation of polarized light

Fe plant pseudomorphs: iron particles taking the form of plant material upon decomposition of the plant

hypocoatings: a coating adjoining the surface with which they are associated, caused by impregnation

interference colors: bright colors displayed by birefringent materials in crossed polarized light

isotropic: a material that has similar properties in all directions; anisotropic is material that has different properties in some directions

Kubiena tin (or box): a metal box for collecting an undisturbed soil sample; it has separate lids top and bottom and is $10 \times 5 \times 3.5 \mathrm{~cm}$

labyrinthine microstructure: material with abundant faunal passages filled to varying degrees with granules

lithofacies (or facies): a subdivision of rock with distinctive characteristics

mamillate: smooth, rounded, interfering spheroidal surfaces

matrix: fine material forming a continuous phase and enclosing coarser material

micropeds: same as peds, but only visible in thin section under the microscope

peds: an individual natural soil aggregate consisting of a cluster of primary particles, and separated from adjoining peds by surfaces of weakness which are recognisable as natural voids or by the occurrence of clay skins

pellicular: peripheral alteration

pisolith: a small, rounded accretionary body in sedimentary rock

plane polarized light (PPL): light, viewed through a polarizing microscope, that has parallel transmission planes

plasma: material $<2 \mu \mathrm{m}$

plasmic fabric: the arrangement of the grains and intergranular voids in the plasma

phytolith: siliceous particle forming the outline of a plant cell

spherulites: a small crystalline body with a radial fabric

tephra: volcanic airfall material

translocation: movement of material through a soil profile

vughy: many irregularly shaped voids 


\section{REFERENCES CITED}

Alberts, Edward E., William C. Moldenhauer, and G. R. Forster

1980 Soil aggregates and primary particles transported in rill and inter-rill flow. Soil Science Society of America Journal $44: 590-595$.

Banda, Richard M., and Freddie Heward

2000 The General Geology of the Niah Caves Area, Sarawak. Unpublished report. Minerals and Geosciences Malaysia Department, Kuching, Malaysia.

Barker, Graeme, Huw Barton, Paul Beavitt, Simon Chapman, Michael Derrick, Chris Doherty, Lucy Farr, David Gilbertson, Chris Hunt, Wayne Jarvis, John Krigbaum, Bernard Maloney, Sue Mclaren, Paul Pettitt, Brian Pyatt, Tim Reynolds, Garry Rushworth, AND Mark STEPHens

2000 The Niah Cave Project: Preliminary report on the first (2000) season. Sarawak Museum Journal 55 (n.s. 76): 111-149.

Barker, Graeme, Dana Badang, Huw Barton, Paul Beavitt, Michael Bird, Patrick Daly, Chris Doherty, David Gilbertson, Ian Glover, Chris Hunt, Jessica Manser, Sue Mclaren, Victor Paz, Brian Pyatt, Tim Reynolds, Jim Rose, Garry Rushworth, and Mark Stephens

2001 The Niah Cave Project: The second (2001) season of fieldwork. Sarawak Museum Journal 56 (n.s. 77) : 37-119.

Barker, Graeme, Huw Barton, Michael Bird, Franca Cole, Patrick Daly, David Gilbertson, Chris Hunt, John Krigbaum, Cynthia Lampert, Helen Lewis, Lindsay Lloyd-Smith, Jessica Manser, Sue Mclaren, Francesco Menotti, Victor Paz, Phil Piper, Brian Pyatt, Ryan Rabett, Tim Reynolds, Mark Stephens, Gill Thompson, Mark Trickett, and Paula WHITTAKER

2002 The Niah Cave Project: The third (2002) season of fieldwork. Sarawak Museum Journal 57 (n.s. 78) : 87-177.

BREWER, ROY

1976 Fabric and Mineral Analysis of Soils. New York: Robert E. Krieger Publishing Co.

Brinkmann, Robert, And Philip Reeder

1995 The relationship between surface soils and cave sediments in west-central Florida, U.S.A. Transactions of the British Cave Research Association 22(3):95-102.

Bullock, Peter, Nicolas Fedoroff, A. Jongerius, Georges Stoops, and T. Tursina 1985 Handbook for Soil Thin Section Description. Wolverhampton: Waine Research Publications.

Courty, Marie-Agnès, Paul Goldberg, and Richard Macphail

1989 Soils and Micromorphology in Archaeology. Cambridge: Cambridge University Press.

FARRAND, William R.

1975 Sediment analysis of a prehistoric rockshelter: The Abri Pataud. Quaternary Research $5: 1-26$.

FitzPatrick, Ewart A.

1984 Micromorphology of Soils. London: Chapman and Hall.

Frank, R.

1968 Cave sediments as palaeoenvironmental indicators, and the sedimentary sequence in Koonalda Cave, in Aboriginal Man and Environment in Australia: 94-104, ed. D. J. Mulvaney and J. Golson. Canberra: Australian National University Press.

1981 Sediments from Leang Burung 2. Modern Quaternary Research in SE Asia 6:39-44.

Gillieson, David, and Mary-Jane Mountain

1983 Environmental history of Nombe rockshelter, Papua New Guinea Highlands. Archaeology in Oceania 18:45-53.

Goldberg, Paul

1979 Micromorphology of Pech-de-l'Aze II sediments. Journal of Archaeological Science 6:1747.

HARRISSON, TOM

1958 The caves of Niah: A history of prehistory. Sarawak Museum Journal 8 (n.s. 12):549595.

1970 The prehistory of Borneo. Asian Perspectives $13: 17-45$. 
Hazebroek, Hans P., and Abang Kashim bin Adang Morshidi

2001 National Parks of Sarawak. Kota Kinabalu: Natural History Publications.

Hutchinson, C. S.

1989 Geological Evolution of Southeast Asia. Oxford: Clarendon Press.

ISAAC, GLYNN

1982 Early hominids and fire at Chesowanja, Kenya. Nature 269:870.

Karkanas, Patagionis, Ofer Bar-Yosef, Paul Goldberg, and Steve Weiner

2000 Diagenesis in prehistoric caves: The use of minerals that form in situ to assess the completeness of the archaeological record. Journal of Archaeological Science 27:915-929.

KIERNAN, KEvin

1983 Relationship of cave fills to glaciation in the Nelson River Valley, Central Western Tasmania. Australian Geographer 15:367-375.

LAFEBER, DAVID

1964 Soil fabric and soil mechanics, in Soil Micromorphology: 351-360, ed. A. Jongerius. Amsterdam: Elsevier.

LEe, JERRY, AND RoB KeMP

1994 Thin Sections of Unconsolidated Sediments and Soils: A Recipe. Egham: University of London, Royal Holloway.

MageE, JoHN

1988 Oriented soil samples from the Tingkayu Basin, in Archaeological Research in South-eastern Sabah: 31-37, ed. Peter Bellwood. Sabah Museum Monograph 2. Kota Kinabalu: Sabah Museum and State Archives.

Magee, J. W., and P. J. Hughes

1982 Thin-section analysis and the geomorphic history of the Colless Creek archaeological site in northwestern Queensland, in Archaeometry: an Australian perspective: 120-128, ed. W. Ambrose. Occasional Papers in Prehistory, No. 12. Canberra: Australian National University.

McConnell, A., and John W. Magee

1993 The contribution of microscopic analysis of archaeological sediments to the reconstruction of the human past in Australasia, in Archaeometry: Current Australasian Research: 131-140, ed. B. L. Fankhauser and J. R. Bird. Canberra: Australian National University.

SCHMID, E.

1963 Cave sediments and prehistory, in Science in Archaeology: 128-138, ed. D. Brothwell and E. S. Higgs. London: Thames and Hudson.

Stiner, Mary C., Stephen L. Kuhn, Steve Weiner, and Ofer Bar-Yosef

1995 Differential burning, recrystallisation, and fragmentation of archaeological bone. Journal of Archaeological Science 22:223-237.

VAN DER MEER, JAAP J. M.

1993 Microscopic evidence of subglacial deformation. Quaternary Science Reviews 12:553-587.

WILFORD, GEORGE E.

1964 The Geology of the Sabah and Sarawak Caves. Bulletin of the Geological Survey, Borneo Region 6. Kuching, Malaysia.

ZuRAina Majid

1982 The West Mouth, Niah, in the prehistory of Southeast Asia. Sarawak Museum Journal 31 (n.s. 52): 1-200.

\section{ABSTRACT}

This is the first detailed study of the micromorphology of archaeologically important cave sediments in the Great Cave of Niah, in the humid tropics of Sarawak, Borneo. Micromorphology is used to describe the sediments and post-depositional alteration, reconstruct the palaeoenvironments, and refine the environmental history of late Pleistocene deposits associated with the human remains (the so-called Deep 
Skull dated to ca. 43,000-42,000 B.P.). Micromorphology provides details of the shape, roundedness, arrangement, and chemistry of grains, aggregates, precipitates, and sedimentary structures that make up the cave sediments. The dominant processes in the West Mouth of the Great Cave of Niah are guano sedimentation, fluvial and shallow pond deposition interrupted by desiccation, mass movement, and chemical weathering. Also important is post-depositional alteration by bioturbation, mineral translocation and reprecipitation, and diagenesis. Micromorphology also provides evidence for short periods of soil development, burnt surfaces, and deposition of small fragments of bone within the sediment. Together this information indicates the fine details of the environment occupied by humans, the scale and effects of the mass movement processes that deformed the beds in which the human remains are preserved, and the taphonomic processes that reworked and redistributed archaeological material within this part of the cave. KEYwords: micromorphology, cave sediments, human remains, Niah Cave, Borneo, humid tropics. 